Piotr Pochel

\title{
Różewicz i symulakry
}

O twórczości poetyckiej autora Kup kota w worku napisano już sporo. Jego poezja była interpretowana przez pryzmat, m.in.: dekonstrukcji [Skrendo 2002a: 11-45], intertekstualności [Pochel 2012], psychoanalizy [Potkański 2004]. Nie zabrakło też odczytań wiążących tę twórczość ze sztuką [Cieślak 1999]. Znalazły się również prace na temat problemu niewyrażalności w tej poezji [Szczukowski 2008]. To, oczywiście, nie wszystkie zagadnienia, które starano się poruszyć, badając twórczość autora Szarej strefy. Dość częstą i szczegółowo omawianą kwestią jest stosunek Różewicza do Boga [Fiut 1995: 157-170; Skrendo 2005: 204-218; Kruszewski 2005]. Jednakże konieczne wydaje się dołączenie do tej gamy interpretacji zgoła innej. Interpretacji przez pryzmat wypracowanej przez Jeana Baudrillarda precesji symulakrów [Baudrillarda 2005. Wszystkie podkreślenia, jeśli nie zaznaczono inaczej, moje - P.P. Warto w tym miejscu zaznaczyć, że próbę taką podjął w swoim artykule Krzysztof Grudnik, którą traktuję jako rekonesans i inspirację do ponownego sięgnięcia po ten temat. Zob. Grudnik 2010: 28-37].

Należałoby przypomnieć, na czym polega proces symulacji i symulakrów. Szahaj pisze:

Jest to kopia bez oryginału, znak bez odniesienia, mapa bez terytorium. To, co znaczone, kopiowane, odtwarzane - znika. Jak powiada Baudrillard, „znak się emancypuje”, uwalnia się od swego odniesienia. Pryska wcześniejsza więź pomiędzy nimi. „Wolny” znak może oddać się całkowicie grze z innymi znakami. Nic go już nie wiąże ze „światem”. Udaje on tylko, że coś z niego znaczy, symuluje znaczenie [Szahaj 2004: 81].

Znaki odklejają się od swojego odniesienia. Wchodzą w relacje $\mathrm{z}$ innymi znakami. Odrywają się od rzeczywistości. Łączą się z innymi 
znakami, by znaczyć coś innego, nowego. To uwalnianie się znaku od swojego odniesienia zauważyć można w wierszu mam żal do Ojca Adama Różewicza. Poeta pisał:

Mickiewicz jest dla mnie
Ojcem i Matką poezji polskiej
więc z szacunkiem i czcią
zwracam się do Rodzica

[Różewicz 2008: 80]

Proces symulacji i symulakrów da się zauważyć już w tytule wiersza. „Ojciec Adam” - to przecież postać biblijna, to ojciec ludzkości, to znak pierwszeństwa i ojcostwa, to Adam z Edenu, to pierwszy człowiek stworzony przez Boga. W wierszu miejsce Adama z Edenu zajmuje Adam Mickiewicz - poeta epoki romantyzmu. „Ojciec Adam” - jako znak - uwalnia się od swojego odniesienia - pierwszego człowieka, ojca ludzkości - oddając cechę pierwszeństwa poecie romantycznemu. I - jak pisze Baudrillard - „hiperrzeczywistość zabezpieczona zostaje przed tym, co wyobrażone, jak też przed wszelką możliwością odróżnienia tego, co rzeczywiste od tego, co wyobrażone, pozostawiając miejsce jedynie na orbitalną powtarzalność modeli i symulacyjne generowanie różnic" [Baudrillard 2005: 7]. Na dwu przeciwnych biegunach ustawiają się dwa znaki: „Ojciec Adam” i Adam Mickiewicz. To, co - zgodnie z teorią Baudrillarda - jest najistotniejsze, to dystans (różnica), jaki wytwarza się między tymi znakami. Pierwszy znak emancypuje, uwalnia się od swego odniesienia (porzuca pierwszeństwo) na rzecz drugiego znaku, który je przyjmuje. Pierwszy znak, uwalniając się od swojego odniesienia, symuluje znaczenie, udaje, że coś znaczy. Tymczasem znak drugi jak gdyby korzysta z odniesienia uprzednio porzuconego przez znak pierwszy. Znak drugi przejmuje zatem funkcję ojcostwa i pierwszeństwa $\mathrm{z}$ tą różnicą, że dotyczyć ona będzie obszaru literackiego, a nie socjologii (ludzi/ludzkości). Drugi znak zaczyna funkcjonować nie tylko jako romantyczny twórca, ale ten twórca, który jest „punktem zero” [Termin utworzony przez Mariana Kisiela. Zob. Kisiel 2000: 49-61] w poezji polskiej - źródłem, 
z którego wyrasta polska poezja. „Ojciec Adam” to oryginal, zaś Adam Mickiewicz - kopia tego oryginału, symulakr. Warto spróbować zaklasyfikować ten typ symulakru do jednego z trzech porządków, które proponuje Baudrillard [2005: 149]. Najtrafniejsze byłoby przypisanie go do pierwszego porządku symulakrów:

symulakry naturalne, naturalistyczne, oparte na obrazie, naśladownictwie i podrabianiu, harmonijne, optymistyczne oraz zmierzające do przywrócenia, odtworzenia bądź ustanowienia w sposób idealny natury na wzór Boga [Baudrillard 2005: 149].

Uważam, że to klasyfikacja w pełni uzasadniona, bowiem „Ojciec Adam” jest swego rodzaju wyobrażeniem ojca wszystkich ludzi, wyobrażeniem pierwszego człowieka, od którego rozpoczęło się życie. Ba!, wyobrażeniem człowieka stworzonego na obraz i podobieństwo Boga. Podobnie ma się sprawa z Adamem Mickiewiczem: Różewicz, zestawiając go z „Ojcem Adamem”, przypisuje mu wszystkie jego cechy, tworząc tym samym obraz zmierzający ku odtworzeniu postaci wykreowanej wzorem Boga. Warto jednak pójść nieco dalej i przyjrzeć się sprawie samego aktu stworzenia ojca ludzkości. Wystarczy przypomnieć sobie, w jaki sposób Bóg stwarzał świat. Przecież to za pomocą słowa dokonywał Najwyższy aktu stworzenia. Wypowiadane przez Boga słowo przybierało formę konkretnego bytu, konkretnego znaku. Bóg, stwarzając człowieka, powiedział: „Uczyńmy człowieka na wyobrażenie nasze, według podobieństwa naszego, a niech panuje nad rybami morskimi, i nad ptactwem niebieskim, i nad zwierzęty, i nad wszystką ziemią, i nad wszystkim płazem, płazającym się po ziemi” [ 1 Moj 1:26]. Słowo miało moc twórczą - stanowi więc oryginał, z którego wywodzi się kopia człowieka. Stąd pierwszy człowiek mógłby być potraktowany również jak swego rodzaju symulakr, kopia słowa.

Słowa tworzą słownik - zbiór wyrazów potrzebnych do porozumiewania się z innymi ludźmi. Różewicz, będący bacznym obserwatorem zmieniającej się rzeczywistości, zauważa zubożałość języka polskiego, jak również ciągłą jego „anglizację” i „amerykanizację”: 
w ciągu 80 lat

zauważyłem że „wszystko”

zamienia się w dziwną zupę

- ale zupę śmierci nie życia

tonę w tej zupie śmierci

wolam po angielsku

help me help me

(po polsku nikt już nie rozumie)

[Różewicz 2002: 16]

Język polski traci swoją niezwykłość. Współcześni nie dbają o kulturę języka - miejsce polskich wyrazów coraz częściej zajmują pożyczki z języka angielskiego:

w suwerennym kraju który odzyskał wolność w roku 1989 a teraz ma odzyskać wolność równość niepodległość zaczął zanikać panujący język polan - przepowiedzieli to zresztą zakichani futurolodzy lingwiści którzy stwierdzili że będą zanikały kolejno języki mniejszych plemion i grup etnicznych - na rzecz języka angielskiego jako języka globalnego i superjęzyka amerykańskiego. Toteż [...] zauważono gwałtowne zubożenie zasobów leksykalnych a nawet parajęzykowych [Różewicz 2002: 7].

Zubożenie leksykalne, o którym wspomina autor Historii pięciu wierszy, jest wyraźnie widoczne u współczesnej młodzieży. Polega ono nie tyle na małym zasobie leksykalnym, ile na zastępowaniu różnych wyrazów, m.in. słowem: „kurwa”. W utworze Wiosna Różewicz pisał:

siedzę gdzieś

ale nie wiem gdzie

wszystko jest stare odwieczne

słońce drzewa kwiaty

dziewczęta $\mathrm{z}$ papierosem $\mathrm{w}$ buzi

chłopięta ze słowem kurwa

(też w buzi) to młody las

[Różewicz 2002: 95] 
Ograniczony zasób słownictwa współczesnych prowadzi do szybszego i łatwiejszego nazywania otaczającej nas rzeczywistości. Nie bez kozery obrałem za przykład słowo: „kurwa”, ponieważ robi ono największą „karierę” w obecnych czasach. Jak stwierdza Różewicz słowo to jest na tyle mocno osadzone we współczesnym języku, że „zastąpiło prawie połowę zasobów językowych” [Różewicz 2002: 7]! Wyraz ten może być przykładem interesującego symulakru. Skądinąd wiadomo, że słowem: „kurwa” określa się kobietę lekkich obyczajów, prostytutkę. Tymczasem ewoluujący język zaszedł tak daleko, że „kurwa” nie tylko odnosi się do tego znaku. Słowu temu często przypisuje się funkcję znaku przystankowego: „w ten sposób proces zanikania mowy polskiej kurwa został przyspieszony" [Różewicz 2002: 7]. Równie często służy jako wyraz, którym można przekazać swoje uczucia - od złości po euforię. Świadczyć to o tym, że słowo: „kurwa” może być symulakrem dwubiegunowym, a więc takim, który może określić rzeczywistość zarówno pozytywnie, jak i negatywnie. Autor Kartoteki zwraca uwagę jeszcze na inne słowo, które jest tak samo popularne, jak wyżej wymieniony wulgaryzm. Chodzi o wyraz: „fajny” odmieniany na wszystkie możliwe sposoby. Różewicz pisze:

zostało nam superuniwersalne słowo fajny które zastępuje słownik filologiczny psychologiczny teologiczny i w ogóle... a odmienia się tak jak dawne różne przymiotniki np. klawy, fajny fajna fajne fajny fajnego fajnemu fajny o! fajny w fajnym a potrafi określić każdego artystę i każde dzieło sztuki jest to słowo które zastąpiło wszystko i oddaje precyzyjnie nasz stosunek do Wszystkiego [Różewicz 2002: 8].

W tym przypadku słowo: „fajny” każdorazowo będzie oznaczało coś pozytywnego, bądź coś pozytywnego czemuś przypisywało. Samo w sobie jest przekazaniem treści typu, że coś jest OK., w porządku, bez zastrzeżeń - podkreślając wartość dodatnią czegoś. Można raczej mówić tutaj o jednobiegunowości symulakru, polegającej tylko na pozytywnym określaniu czegoś/kogoś. 
Baudrillard pisał:

Wszystko ulega przekształceniu w swoje przeciwieństwo po to, by przetrwać w oczyszczonej formie. Wszelka władza, wszelkie instytucje mówią o sobie przez zaprzeczenie, by poprzez symulowaną śmierć podjąć próbę uniknięcia rzeczywistej agonii [Baudrillard 2005: 28].

Wyraźnie widoczne jest to w tomie Płaskorzeźba. Różewicz wielokrotnie wypowiada się na temat wiary poprzez zaprzeczenie, by właśnie pielęgnować w swojej świadomości to, że Bóg w gruncie rzeczy jest dobry i miłosierny. Problem ten poruszyła Zofia Zarębianka:

Różewicz, odrzucając Boga, ocala zarazem ideę absolutu rozumianego jako nieskazitelna doskonałość, dobro i pełnia. Lepiej bowiem [...] dla ocalenia samej idei Boga jest przyjąć Jego nieistnienie, niż założyć taki Jego wizerunek, w którym poprzez przyzwolenie na zło, a konkretnie: przyzwolenie dla holocaustu, byt Boski nabierałby cech sadystycznego okrutnika [Zarębianka 2011: 178].

To zaprzeczenie Boga, które ma pełnić funkcję ocalającą, zauważyć można w wierszu bez:

życie bez boga jest możliwe życie bez boga jest niemożliwe

[Różewicz 1991: 7],

jak również w utworze Cierń, gdzie wyznaje swoje anty-Credo [Fiut 1995: 158]:

nie wierzę

nie wierzę od przebudzenia

do zaśnięcia

nie wierzę od brzegu do brzegu

mojego życia

[Różewicz 1999: 61] 
Płaskorzeźba a zaraz po niej Historia pięciu wierszy są chyba najbardziej symulakrycznymi tomikami Różewicza. Zwrócił już na to uwagę Andrzej Skrendo [2002b: 326], zaznaczając, że zarówno w pierwszym, jak i w drugim tomie obok wersji drukowanej występuje wersja rękopiśmienna. W Płaskorzeźbie widnieje tylko jedna wersja rękopiśmienna obok wersji drukowanej. Inaczej jest w Historii... Wystarczy otworzyć tę książkę na wierszu, który ostatecznie nosi tytuł Przypomnienie. Poeta zamieszcza trzy wersje rękopiśmienne, jedną $\mathrm{w}$ maszynopisie $\mathrm{z}$ naniesionymi odręcznie poprawkami i jedną drukowaną, m.in. na łamach czasopisma „Twórczość”. Rzecz nie wydaje się zbytnio skomplikowana, gdyby wziąć pod uwagę relacje między pierwszą a drugą wersją rękopiśmienną. Zdecydowanie druga będzie kopią pierwszej, a więc jej symulakrem. Sprawa komplikuje się w momencie, kiedy w grę wchodzi wersja trzecia. Nie może być tylko symulakrem drugiej wersji, bo przed nią była jeszcze pierwsza. Proponuję, by mówić w tym przypadku podwojonej symulakryczności tej wersji, ponieważ zachodzące relacje nie ograniczają się w tym przypadku do wersji drugiej i trzeciej, ale dotyczą również wersji pierwszej. „Stopień symulakryczności” wzrośnie o jeden punkt, gdyby zbadano wersję czwartą tego wiersza, na którą naniósł poeta odręczne poprawki. Mowa będzie zatem o potrojonej symulakryczności, wchodzącej w relacje aż z trzema poprzednimi wersjami. Podobnie byłoby z wersjami piątą i następną.

Precesja symulakrów niewątpliwie jest widoczna w twórczości poetyckiej Różewicza. Emancypacja znaków, ich uwalnianie się od swego odniesienia, z pewnością $\mathrm{w}$ jakimś stopniu zależą od zmieniającej się rzeczywistości, która znakami jest przepełniona. To świat, który jest chaotyczny, nie poukładany, pomieszany:

na początku była gęsta zupa w której pod wpływem światła (i ciepła)

powstało życie

z tej zupy wyszedł stwór a raczej wyszło coś 


\author{
co przemieniło się w drożdże \\ w szympansa \\ po jakimś czasie pojawił się bóg \\ który stworzył człowieka \\ mężczyznę i kobietę \\ słońce i kleszcza
}

[Różewicz 2002: 15]

Świat otaczający człowieka przypomina olbrzymi kocioł, w którym gotuje się zupa - swego rodzaju „poppapka” [Gutkowska 2006: 76]. Człowiek jest w niej ugotowany, ponieważ jako reprezentant kultury ponowoczesnej, nie nabył umiejętności selekcji i wyróżnienia tego, co wartościowe i godne uwagi [Gutkowska 2006: 77]. Rzeczywistość staje się zlepkiem [Skrendo 2002: 317] różnych fragmentów (wystarczy przywołać tu chociażby wiersz tj.: mam żal do Ojca Adama czy Budowanie wieży Bubel), czasem do siebie nie pasujących i bardzo odległych - to rzeczywistość eklektyczna [Lyotard 1996: 53].

W jednym ze swoich artykułów Andrzej Szahaj stara się odpowiedzieć na pytanie: jak zostać geniuszem w epoce postmodernizmu? [Szahaj 2004: 56-60]. W mojej ocenie, to trudne pytanie. Niełatwo jest uchodzić dziś za geniusza, jeśli żyje się w kulturze powtórzeń [Szahaj 2004: 59]. Trzeba wykazać się zadziwiającą wyobraźnią i kreatywnością, by zabiegać o miano geniusza XXI wieku. Przecież w kulturze XXI wieku wszystko już było. Uważam jednak, że warto byłoby zastanowić się nad geniuszem Różewicza, analizując jego twórczość. Dotąd nikt z badaczy zajmujących się twórczością autora Płaskorzeźby nie pytał o jego geniusz pisarski. Dlatego tym bardziej sądzę, że warto poszukać odpowiedzi na pytanie, czy Różewicz jest geniuszem XXI wieku, jak niegdyś Kochanowski, Mickiewicz, Słowacki czy Peiper?

\title{
Bibliografia
}

Baudrillard J. [2005], Symulakry i symulacja, Królak S. (przeł.), Sic!, Warszawa. Biblia Święta to jest Cate Pismo Starego i Nowego Testamentu z hebrajskiego i greckiego języka na polski pilnie i wiernie przettumaczone [1959], Warszawa. 
Cieślak R. [1999], Oko poety. Poezja Tadeusza Różewicza wobec sztuk wizualnych, Słowo/Obraz/Terytoria, Gdańsk.

Fiut A. [1995], Pytanie o tożsamość, Universitas, Kraków.

Grudnik K. [2010], Ocalić od wyrażenia. Symulakry i pop w „Kup kota w worku”, [w:] Czytanie Różewicza. Wokół książki „Kup kota w worku (work in progress)", Materiały II studenckiej konferencji Koła Naukowego Polonistów, Dutka E. (red.) przy współudziale Mikrut I. i Szczepanek A., Oficyna Wydawnicza WW, Katowice.

Gutkowska K. Z. [2006], Różewiczowska historiozofia ponowoczesności, [w:] Nasz wiek XX. Style, tematy, postawy pisarskie, Opacka A., Kisiel M. (red.), Agencja Artystyczna PARA, Katowice.

Kisiel M. [2000], Pamięć, biografia, słowo. Szkice o poetach dwóch generacji, Gnome, Katowice.

Kruszewski W. [2005], Deus desideratus. Sacrum w poetyckim dziele Tadeusza Różewicza, Wydawnictwo Katolickiego Uniwersytetu Lubelskiego, Lublin.

Lyotard J-F. [1996], Odpowiedź na pytanie: co to jest postmodernizm?, Markowski M.P. (przeł.), [w:] Postmodernizm. Antologia przekładów, Nycz R. (oprac.), Wydawnictwo Baran i Suszczyński, Kraków 1996.

Pochel P. [2012], Intertekstualne gry w liryce Jana Lechonia i Tadeusza Różewi$c z a$, Wydawnictwo i-Press, Kraków.

Potkański J. [2004], Sobowtór. Różewicz a psychoanaliza Jacquesa Lacana i Melanii Klein, Semper, Warszawa.

Różewicz T. [2008], Kup kota w worku (work in progress). Biuro Literackie, Wrocław.

Różewicz T. [1999], Matka odchodzi, Wydawnictwo Dolnośląskie, Wrocław. Różewicz T. [1991], Płaskorzeźba, Wydawnictwo Dolnośląskie, Wrocław. Różewicz T. [2002], Szara strefa, Wydawnictwo Dolnośląskie, Wrocław. Skrendo A. [2002a], Cień matki. Zapis dekonstrukcji, [w:] Matka odchodzi. Rozbiory, Iwasiów I. i Madejski J. (red.), Wydawnictwo Naukowe Uniwersytetu Szczecińskiego, Szczecin.

Skrendo A. [2002b], Tadeusz Różewicz i granice literatury. Poetyka i etyka transgresji, Universitas, Kraków.

Skrendo A. [2005], Poezja modernizmu. Interpretacje, Universitas, Kraków.

Szahaj A. [2004], Zniewalajaca moc kultury. Artykuly i szkice z filozofii kultury, poznania i polityki, Wydawnictwo Uniwersytetu Mikołaja Kopernika, Toruń.

Szczukowski D. [2008], Tadeusz Różewicz wobec niewyrażalnego, Universitas, Kraków. 